\title{
The Role of Pragmatics for Grammatical Change: The Case of French Preverbal Non ${ }^{1}$
}

Pierre Larrivée, Aston University

P.Larrivee@Aston.ac.uk

\begin{abstract}
What is the role of pragmatics in the evolution of grammatical paradigms? It is to maintain marked candidates that may come to be the default expression. This perspective is validated by the Jespersen cycle, where the standard expression of sentential negation is renewed as pragmatically marked negatives achieve default status. How status changes are effected, however, remains to be documented. This is what is achieved in this paper that looks at the evolution of preverbal negative non in Old and Middle French. The negative, which categorically marks pragmatic activation (Dryer 1996) with finite verbs in Old French, loses this value when used with non-finite verbs in Middle French. This process is accompanied by competing semantic reanalyses of the distribution of infinitives negated in this way, and by the co-occurrence with a greater lexical variety of verbs. The absence of pragmatic contribution should lead the marker to take on the role of default, which is already fulfilled by a well-established ne ...pas, pushing non to decline. Hard empirical evidence is thus provided that validates the assumed role of pragmatics in the Jespersen cycle, supporting the general view of pragmatics as supporting alternative candidates that may or may not achieve default status in the evolution of a grammatical paradigm.
\end{abstract}

\section{Introduction}

The purpose of this paper is to evaluate the role of pragmatics for the historical evolution of grammatical systems. The system considered is that of negation, which is claimed to follow a pattern of change known as the Jespersen cycle ${ }^{2}$. The cycle is illustrated by Jespersen himself with reference to French, in which a weakening preverbal negative is reinforced by a postverbal item that after a period of conjoined use, becomes the default expression of negation. The initial emergence of postverbal reinforcement, before the conjoined use with the preverbal negative becomes the unmarked option, has been interpreted as promoted by presuppositional contexts. Such contexts are defined by Schwenter (2006) and Mosegaard Hansen and Visconti (2007) as activated, where the underlying proposition is accessible to the hearer because it has been mentioned before or can be inferred through accommodation or contextual relations. The activated status of Old French post-verbal reinforcements finds contrasted empirical support. Categorical evidence that activation characterises a marked negative is provided by preverbal negative non. This use of the marker is interesting in itself, given that its disappearance is a specificity of French among Romance languages (van Hoecke 2006); this disappearance may be a seen as a step in the weakening of the preverbal marker that is conceived as an impetus of the negative cycle that again seems more advanced in

\footnotetext{
${ }^{1}$ This work has been developed thanks to constructive input from the two anonymous reviewers, from Bernard Combettes, Richard Ingham, Evelyne Oppermann-Marsaux, David Trotter, and from the audiences of the January 2009 Romance Linguistics Seminar at Cambridge and of the April 2009 Meaning and Interaction international conference at UWE. The usual disclaimers apply.

${ }^{2}$ A full bibliography of work on the Jespersen cycle is provided on the web site of the international network Cycles of Grammaticalization supported by the Leverhulme Foundation (http://www1.aston.ac.uk/lss/research/research-projects/cycles-ofgrammaticalization/).
} 
French than in its Romance counterparts. More generally, the decline of preverbal non provides critical data for the comprehension of the role of pragmatics for grammatical change.

This paper provides for the first time hard categorical evidence as to the involvement of pragmatic activation in the evolution of the grammatical paradigm of negation. It is shown how that pragmatic function supports marked negatives, and that the loss of that specialised contribution leads to a change of status of the item, whether it be decline for non or accession to default status as with postverbal reinforcements. Change of status is accompanied by semantic reanalyses of the distribution of the contexts where preverbal non should be found, as the negative occurs with a larger number of different verbs, a process hypothesised to characterise the crucial and undocumented change of pas from a noun meaning 'step' used with predicates of movement to a polarity indefinite indicating a minimal measure ${ }^{3}$. These novel results are presented as follows. Section 2 looks at the background assumptions about activation and change in the marking of negation, and shows how these assumptions are supported by preverbal non in Old French ${ }^{4}$. The situation in Middle French is characterised in section 3, where it is shown that loss of activation is correlated to use with infinitive verbs. Why that distribution leads to the loss of the pragmatic value of activation and the obsolescence of the item is speculated upon in the conclusion, which summarises the argument. It is proposed that the role of pragmatic functions for evolution is to support the marked items in a grammatical system, and that loss of that contribution can only lead to the obsolescence of an item that cannot gain default status against a wellestablished unmarked expression.

\section{Looking for activation}

The question that the Jespersen cycle raises is why the grammatical system of negation should change from a simple preverbal item to a dual embracing marker with a preverbal and a postverbal element. The answer generally provided is that the phonetically reduced preverbal item fails to communicate negation unambiguously, and that this is clarified by a polarity item that most often occurs after the negative marker. Before it becomes an element of the standard expression of negation, the postverbal item is assumed to be associated to a pragmatic value. That value is hypothesised to be emphasis (Detges and Waltereit 2002, Eckardt 2006, Hopper and Traugott 2003, Kiparsky and Condoravdi 2006, to name only recent work) or activation (Schwenter 2006, Mosegaard Hansen and Visconti 2007). Relying on a clear intuition, the former is difficult to document unambiguously. That is because ancient written texts do not provide systematic indications of emphasis, because these indications are varied in form ranging from prosodic cues to degree modifiers, and because textual progression is not shaped in an

\footnotetext{
${ }^{3}$ The use of a negative with a larger number of verbs is partly documented by Hoeksema (2009) on the basis of contemporary English. A case of lexical expansion in historical evolutions is clearly evidenced by Traugott (2008) who reports that as they become more established, pseudo-clefts include an ever increasing number of verbs, from be (more) in the $18^{\text {th }} \mathrm{c}$ to a series including want, say, do, know in the $19^{\text {th }}$. A reviewer further brings to my attention the work by Himmelmann (2004), for whom "context expansion is part of the definition of (increasing) grammaticalization."

${ }^{4}$ Archaic French where non is the only verb negative is not considered here, given the brievity of the two ninth century texts available, and the potential interference from latin for both (Kawaguchi 2009). Latin evidences the preverbal use of non since Terence $\left(2^{\text {nd }} \mathrm{c}\right.$ BC) according to van Hoecke (2006: 802) and Orlandini (2001: 306).
} 
immediately recognised fashion. Because textual progression is influenced by it, activation can be more readily tested (Larrivée 2010). The notion of activation constitutes a reformulation of the notion of presupposition (Dryer 1996) as information that is accessible to the hearer. Accessibility of a proposition follows from being explicitly used in the antecedent context, or being inferable from accommodating constructions or contextual relations. The nature of what introduces the presupposition therefore allows a distinction to be made between explicit activation, where a proposition is presupposed because it has been used before, and implicit activation, where presupposition follows from contextual inferences or accommodating constructions (see Larrivée 2009, and also Visconti 2009). Building on the work by Schwenter (2006, 2005) showing that the use of some Romance post-verbal negatives depends on activation, Mosegaard Hansen and Visconti (2007) set out to document the role of activation for the emergence of post-verbal negatives ${ }^{5}$ in Old French and Old Italian. Old French provides cases of post-verbal negatives in explicitly activated environments, as in (1):

$$
\begin{aligned}
& \text { "Se vous me voulés croire, ..." Il ne le vorent pas croire, ... (Joinville, P364-5) } \\
& \text { 'If you-NOM me-ACC want-PR believe, ... They-NOM ne him-ACC } \\
& \text { want-PR pas believe' } \\
& \text { "If you'll believe me,..." They wouldn't believe him,... (Mosegaard } \\
& \text { Hansen and Visconti 2007: 10, example (32)) }
\end{aligned}
$$

The use of post-verbal pas would be motivated by the fact that the proposition is accessible to the hearer by virtue of the fact that it has been used explicitly before. Implicit activation is however concerned in the vast majority of cases, as in (2):

$$
\begin{aligned}
& \text { Ne l'oï dire, ne jo mie nel sai (Roland v. 1386) } \\
& \text { 'Ne it-ACC hear-PST said, neither I-NOM mie ne it-ACC know-PR' } \\
& \text { I haven't been told, I don't know it [at all] (Mosegaard Hansen and } \\
& \text { Visconti 2007: 22, example (101)) }
\end{aligned}
$$

The second proposition about the speaker being aware of a fact would be activated through the inference raised by the immediately preceding proposition about the speaker having heard about it, making it possible to have postverbal mie. The use of the postverbal negative element in early French is not always clearly dependent on activated propositions however. A detailed examination of the nine manuscripts of the thirteenth century chanson de geste Le Charroi de Nimes by Schøsler (2008) shows some considerable variation: some explicitly activated sequences are found without a reinforcement in any of the manuscripts, and a given sequence that is not discernably activated is found with a simple negation in some of the manuscripts and a reinforced one in others ${ }^{6}$. The

\footnotetext{
${ }^{5}$ The considered post-verbal markers are mie and pas, rightly so as these are the most frequent in Old French. Whether point, goutte and other markers follow the same trajectory remains to be considered, as suggested by a reviewer.

${ }^{6}$ Bernard Combettes points out that it would be interesting to consider the variation in the different manuscripts according to their date. One reviewer claims that « a close examination of Schøsler examples shows that those instances where she claims bipartite negation is used without prior activation are in fact open to an analysis as activated. » This may or may not be the case, and the point is that it is important to apportion this to use well-defined criteria, lest the hypothesis becomes undemonstrable. An analysis that conclusively calls into question the explicitly activated status of post-verbal reinforcement in French is provided by Larrivée (2010). A further point noted by a
} 
contrasted empirical support for the notion may be due to the fact that the available data are simply posterior to the change: post-verbal reinforcement is already attested in late Latin (Orlandini 2001: 70-71). That would explain why post-verbal markers are still to a significant degree associated with activation, although mainly to implicit activation. Implicit activation would have to be assumed to an intermediary stage between the initial state of explicit activation characterising emerging post-verbal negatives and their final state as elements of the default expression of negation dissociated from any pragmatic contribution if the hypothesis about the trajectory of these markers is to be maintained. The credibility of the hypothesis would crucially depend on the ability to provide attested evidence about the role of activation in the evolution of some negative markers.

The unambiguous role of activation for the evolution of negatives can be demonstrated by the uses of preverbal non in Old French. It is little studied (Larrivée 2010; see also Breitbarth and Haegeman 2010), but the article by Reid provides excellent reasons to believe that activation may be involved with this use; described as "markedly affective" (1939: 306), non modifies vicarious verbs avoir, être, faire and modals in a sequence that is "always in some degree elliptical, the sentence being meaningless except with reference to what precedes" (1939: 306). This is exactly what we are looking for of course, as dependence on a previous proposition signals activation of the proposition containing the negative. Non is used for "denying the truth of a statement, but also making a negative reply to a question, and refusing to obey a command" (1939: 306). These functions are illustrated in turn by the following examples.

Honte $i$ avrai et reproche toz tans

'Shame I have-FUT and reproaches all times'

- Non avrez, sire, dist Viviens li frans. (Aliscans, 204-5)

'Not have-FUT-2PP, Sir, said Viviens the noble-one'

J'aurai pour toujours honte et reproches.

- Non, seigneur, répond le noble Vivien. (Buridant 2000: 704)

"I will forever have shame and reproaches."

"- Not so, Sir, answered the noble Vivien."

Dist Chantecler : Renart cousin,

Vos me volez traire a enging?

'You me-ACC want-PR-2PP draw at engine'

- Certes, ce dist Renart, non voil (RenartR, I, 4365-67)

'Certainly, this said Renart, not want-PR-1SG

Chantecler dit: Renart, mon cousin, vous voulez me berner.

- Assurément, dit Renart, ce n'est pas du tout mon intention. (Buridant 2000: 704)

"Chantecler said: Renart, my cousin, you want to fool me?

- It is certainly not at all my intention, said Renart"

Nel ferez/

Par vos li mant qu'il nos soit secoranz

'By you him-DAT ask that he us-DAT be-SUBJ rescuing

- Non feré, sire, dist Bertrand li vaillanz. (Aliscans 208-209)

'Not do-FUT-1SG, Sir, said Bertrand the brave'

reviewer is that an unmarked negative should have license to appear in marked environments. That is well taken, but does not address the case of reinforcements in discourse-new environments documented by Larrivée (2010) and also observed by Schøsler: in verse 2897, eight manuscripts have the preverbal negative only with a discourse-new sequence, and one unexpectedly has mie. 
Vous lui demanderez de notre part de venir nous secourir.

- Non, seigneur, répliqua Bertrand le valeureux. (Buridant 2000: 704)

"You will ask him to come and rescue us

- I will not do so, Sir, replied Bertrand the brave."

The situation described by Reid is validated by the texts contained in the Base de français médievval, which lead to three further syntactic observations. On the one hand, it is possible to embed under the verb to say the sequence in which non is used: 1 occurrence of this is found in La Queste del Saint Graal (1220), 2 in La Mort le Roi Artu (1230), 1 in Tristan en prose (tome 1) $\left(13^{\text {th }} \mathrm{c}\right)$, and 2 in Coutumes de Beauvaisis (1283).

Et tu deis que non feroies (La Queste del Saint Graal, 1220)

And you say-PR-2SG that non do-PR-2SG

And you say that you will not

This goes against the predictions made by the analysis by Godard and Marandin (2006) for whom activated propositions must be a root clause. The second observation is that overt subject is inverted with non, suggesting verb raising to complementiser position (Vance 1997 among others). One exception was found in the versified Enéas (around 1155) (3 further cases are cited by Collas 1964: ciii):

$$
\begin{aligned}
& \text { Sire, por coi m'avez traie ? } \\
& \text { Sir, why did you betray me? } \\
& \text { - Ge non } \underline{a i} \text {, voir, la moie amie. } \\
& \text { I non have-PR-1SG } \\
& \text { I have not, in truth, my friend }
\end{aligned}
$$

Finally, as pointed out by Reid, the use is found with conjugated verbs, as shown by the following table that provides against the morphology of the verb the number of occurrences in the prose texts of the corpus

\begin{tabular}{|l|l|l|l|l|l|l|}
\hline & $\begin{array}{l}\text { Li Quatre } \\
\text { Livre des } \\
\text { Reis } \\
(1190)\end{array}$ & $\begin{array}{l}\text { La Queste } \\
\text { del Saint } \\
\text { Graal } \\
(1220)\end{array}$ & $\begin{array}{l}\text { La Mort le } \\
\text { Roi Artu } \\
(1230)\end{array}$ & $\begin{array}{l}\text { Tristan en } \\
\text { prose } \\
(\text { tome 1) } \\
\left(13^{\text {th }} \mathrm{c}\right)\end{array}$ & $\begin{array}{l}\text { Coutumes de } \\
\text { Beauvaisis } \\
(1283)\end{array}$ & \\
\hline Finite & 7 & 9 & 8 & 3 & 4 & 31 \\
\hline Non-finite & 2 & 0 & 0 & 0 & 0 & 2 \\
\hline Totals & 9 & 9 & 8 & 3 & 4 & 33 \\
\hline
\end{tabular}

Table 1. Non with finite and non-finite verbs in some Old French prose texts

The two non-finite contexts were found in the Anglo-Norman ${ }^{7}$ late twelfth century biblical translation Li Quatre Livre des Reis.

\footnotetext{
${ }^{7}$ A reviewer wonders whether these cases are relevant, given that «Anglo-Norman is in many ways quite different from other OF dialects. » The traditional view from French scholars was indeed of Anglo-Norman as a bastardised variety of medieval French; new analyses proposed by Richard Ingham notably demonstrate alignment of Anglo-Norman to continental varieties for syntax and pragmatics until the 1360's.
} 
(8) a. Amon [...] sa volented li descuvrid. Respundi la pulcele: 'Nu faire, bel frere, nu faire tel sotie' (Liv Reis 81; Anglo-Norman dictionary. Reid 1939: 306, note 4)

Amon told her what he intended. The maiden answered: 'Do not do, stepbrother, do not do such foolishness.'

b. si li dís : 'Quele ure devum en Ramoth Galááth pur batáille fáire alér ú nun alér? (Liv Reis)

then he told him: 'What time must we go to Ramoth Galááth to do battle, or should we not go?

The first example aligns with conjugated examples as it involves an imperative-like infinitive. It may even be that the $n u$ is not a variant of non, but rather a fusion of clitics ne and le (David Trotter, personal communication). ${ }^{8}$ The intervention of non is not in doubt in the second illustration. The beauty of this example is that the second infinitive aler 'to go' repeats in the negative the positive infinitive that is the first member of the conjunct; in other words, this involves explicit activation. This provides strong support for the activation analysis.

Outside this corpus, one case of disputable activation is attested from Troie en prose $\left(13^{\text {th }} \mathrm{c}\right)$ by Garcia (1993: 52-53):

Mais celui qui est honis en cest siecle en l'autre avra grant vergoigne. Sire, mout est mon cuer estroit quant je pens ce que vos aves fait et quant si faite heine vous portent les dieus d'enfer par cui si fait mal vos est avenus que grant corage vos vint de non revenir en la cite.

"But the one who is banished in this century and the other will have great shame. Sir, my heart sinks when I think about what you did and about the hatred that hell's devil must have for you, because of which so much wrong was done to you that you found the courage not to come back in the city."

However, since banishment is mentioned in the sentence before the evocation of not returning to the city, this reasonably involves implicit activation. The observation that implicit activation cases emerge subsequently to explicit activation supports the presumption that post-verbal negatives found to be implicitly activated in attested sources might well have been explicitly activated at an initial stage.

The conclusion must be that activation does characterise the propositions in which non is found in Old French. Whether this carries over to Middle French is considered in the next section.

\section{Middle French}

The relation between activation and preverbal non is categorical in Old French. Does Middle French see the continuation of this relation? This can only be established by an extensive empirical investigation. This is conducted on the basis Middle French prose texts available in the Base de français médiéval, as versified productions may reflect

\footnotetext{
${ }^{8}$ The presence of an underlying accusative pronoun is however unlikely in retrospect, as one of the adjacent infinitives has a direct object, as pointed out to me by Bernard Combettes.

${ }^{9}$ Bernard Combettes raises the issue whether Joinville should be considered Middle French. With all due respect to the unresolved debate at to when Old French stops and
} 
stylistically marked usage. Eleven texts are concerned - Jean de Joinville : La Vie de Saint Louis (1298-1309), Chronique de Morée (1320-24), Froissart : Chroniques (between 1369 and 1400), Les XV Joyes de Mariage (around 1400), excerpts of Enguerrand de Monstrelet : Chronique (1441), Le Roman du Comte d'Artois (1453-67), Les Cent Nouvelles Nouvelles (14561467), Antoine de la Sale : Jehan de Saintrée (1456), Le Roman de Jehan de Paris (1494), Commynes : Mémoires (between 1490 and 1505) and Rabelais, Le Tiers Livre (1546). The exhaustive search for non yielded 710 examples that were divided in six uses. The prefix use (Taylor 1976, van Hoecke 2006) concerns non relating to a lexeme as illustrated by frequent nonchaloir, nonobstant, nonpourtant. Modification of a phrase comprises the two cases of constituent negation, with expressions relating to a lexical alternative such as degree terms plus 'more', and corrective constituent negation, with expressions to which an alternative is provided by the context. Focus constructions are found in conditionals that cancels the negation of the main clause to imply an assertion (as in the comparable modern-day English he is nothing if not wise), and the corpus evidences a movement from si $X$ non to si non $X$ that will produce modern French sinon 'except'. Pro-sentential refers to autonomous uses standing for a proposition, with or without adjuncts, in coordination and subordination. In direct competition with $n e$, the preverbal uses account for $22 \%$ of occurrences with 157 tokens. An example of each use is provided below:
a. Prefix
[...] les gens de bas estat, noiseux, rioteux et non sachans de la guerre, [...] (Monstrelet)
the people of lower extraction, looking for trouble, riotous and ignorant of war
b. Constituent
Il enclinerent le roi, et non plus avant. (Froissart)
They assented to the king, and no more.
c. Contrastive
laquelle chose seroit grant paine de escripre et non de lire.
d. Focus
which thing would be a great shame to write and not to read
que onques ne furent aperceü ne santi, si non a l'endemain. (Morée)
'that never ne be-3-PL seen neither heard, if not at the next-day'
that they be seen or heard only the next day
e. Pro-sentential
et le fist lever de court, vousist ou non, (Froissart)
and he made him leave the court, whether he wanted to or not

The preverbal use is thus well-established in Middle French (see the convergent evaluation from Hirschbüler and Labelle 1997: 488 and Chen 2010: 100ss). Subsequent occurrences found in the electronic data base of mainly literary texts Frantext between 1600 and 1800 are the 2 cases of non suis 'not am' in Béroalde de Verville (1610, Le Moyen de parvenir, p. 276, 77 Committimus and p. 377, 104 Satyre); 1 example is found in the 1669 play $L ' A$ vare by Molière:

Valère. $-[\ldots]$ je proteste de ne prétendre rien à tous vos biens, pourvu que vous me laissiez celui que j'ai.

Middle French starts, the concern does nonetheless not have impact on this work as that particular text contibutes no occurrence. 
Harpagon. - Non ferai, de par tous les diables! (Molière, 1669, L'Avare, Acte $\mathrm{V}$, Scène III)

- I assure you that I make no claim to any of your goods if you leave me the ones I have.

- I will not by all the devils!

Reid (305, note 1) states that the last occurrence adduced by grammarians Haase and Brunot is Regnard (1708, Le Légataire universel, v, vii). Three cases of decidedly archaic style are found in Frantext after 1800 - Moreas' 1904 verse translation of Iphigénie "Non violant les lois du ciel et de la terre, / non, je ne tuerai pas mes enfants pour te plaire !" and two latinate occurrences in the 1920 Dictionnaire de théologie catholique, such as "La théodicée répond à un mouvement est d'expansion et non est d'humilité."

The consideration of the uses in the corpus reveals the same syntactic parameters as in Old French. Embedding is one of the indirect constructions that extend the use of preverbal non modifying a finite verb beyond the prototypical root proposition following a sequence by another speaker: subordinated and coordinated sequences from the same speaker are found (both in Morée, all in Froissart, none in Quinze Joies, 4 out of 5 in Artois, none in de la Salle, 7 out of 31 in Cent Nouvelles, 1 out of 2 in Jehan de Paris, none in Commynes, 1 in Rabelais), to represent $46 \%$ of the 57 relevant occurrences. When in a root context, subject inversion is possible, and categorical in the corpus: no preverbal subject is found with preverbal non.

Both issues of syntactic dependence and status of subject are involved in the major innovation for non in Middle French, that is the use with infinitives. The distribution with finite and non-finite verbs in Middle French prose texts where more than 10 occurrences of non are found is summarised in the table below:

\begin{tabular}{|l|l|l|l|l|l|l|}
\hline & $\begin{array}{l}\text { Chronique } \\
\text { de Morée } \\
(1320)\end{array}$ & $\begin{array}{l}\text { Froissart : } \\
\text { Chroniques } \\
(1369- \\
1400)\end{array}$ & $\begin{array}{l}\text { Antoine } \\
\text { de la Sale: } \\
\text { Jehan de } \\
\text { Saintrée } \\
(1456)\end{array}$ & $\begin{array}{l}\text { Cent } \\
\text { Nouvelles } \\
\text { Nouvelles } \\
(1456-\end{array}$ & $\begin{array}{l}\text { Rabelais : } \\
\text { Le Tiers } \\
\text { Livre }(1546)\end{array}$ & \\
\hline Finite & $2(9 \%)$ & $11(44 \%)$ & $10(55 \%)$ & $31(57 \%)$ & $3(20 \%)$ & 57 \\
\hline Non-finite & $20(91 \%)$ & $13(66 \%)$ & $8(45 \%)$ & $23(43 \%)$ & $13(80 \%)$ & 77 \\
\hline Totals & 22 & 24 & 18 & 54 & 16 & 134 \\
\hline
\end{tabular}

Table 2. Non with finite and non-finite verbs in some Middle French prose texts

There is a clear presence of the use with infinitives, in stark contrast to Old French that provides virtually no such case. This is confirmed by the more detailed breakdown of tense distributions in all the prose texts of the corpus.

\begin{tabular}{|l|l|l|l|l|l|l|l|l|l|}
\hline & \multicolumn{9}{|l|}{ Finite verb } \\
& $\begin{array}{l}\text { Past } \\
\text { Historic }\end{array}$ & Imperfect & Present & Future & Conditional & Totals & Infinitive & $\begin{array}{l}\text { Present } \\
\text { Participle }\end{array}$ & Totals \\
\hline $\begin{array}{l}\text { Chronique de } \\
\text { Morée } \\
24)\end{array}$ & 0 & 0 & 1 & 0 & 1 & 2 & 20 & 0 & 20 \\
\hline $\begin{array}{l}\text { Froissart: } \\
\text { Chroniques } \\
(1369-1400)\end{array}$ & 9 & 1 & 1 & 0 & 0 & 11 & 13 & 0 & 13 \\
\hline $\begin{array}{l}\text { Les XV Joyes de } \\
\text { Mariage }\end{array}$ & 0 & 0 & 3 & 0 & 3 & 6 & 0 & 0 & 0 \\
\hline
\end{tabular}




\begin{tabular}{|c|c|c|c|c|c|c|c|c|c|}
\hline (around 1400) & & & & & & & & & \\
\hline $\begin{array}{l}\text { Enguerrand de } \\
\text { Monstrelet: } \\
\text { Chronique } \\
\text { (excerpts) } \\
\text { (1441) }\end{array}$ & 0 & 0 & 0 & 0 & 0 & 0 & 3 & 0 & 3 \\
\hline $\begin{array}{l}\text { Le Roman du } \\
\text { Comte d'Artois } \\
\text { (1453-67) }\end{array}$ & 2 & 0 & 2 & 0 & 1 & 5 & 3 & 0 & 3 \\
\hline $\begin{array}{l}\text { Antoine de la } \\
\text { Sale: Jehan de } \\
\text { Saintrée (1456) }\end{array}$ & 1 & 1 & 3 & 5 & 0 & 10 & 6 & 2 & 8 \\
\hline $\begin{array}{l}\text { Les Cent } \\
\text { Nouvelles } \\
\text { Nonvelles } \\
(1456-1467)\end{array}$ & 6 & 3 & 11 & 11 & 0 & 31 & 16 & 7 & 23 \\
\hline $\begin{array}{l}\text { Le Roman de } \\
\text { Jehan de Paris } \\
\text { (1494) }\end{array}$ & 0 & 0 & 1 & 1 & 0 & 2 & 0 & 0 & 0 \\
\hline $\begin{array}{l}\text { Commynes: } \\
\text { Mémoires } \\
\text { (around 1490- } \\
\text { 1505) }\end{array}$ & 0 & 0 & 1 & 0 & 0 & 1 & 3 & 0 & 3 \\
\hline $\begin{array}{lr}\text { Rabelais: } & \text { Le } \\
\text { Tiers } & \text { Livre } \\
(1546) & \end{array}$ & 0 & 0 & 1 & 1 & 1 & 3 & 5 & 8 & 13 \\
\hline Totals & & & & & & & & & 86 \\
\hline
\end{tabular}

Table 3. Non with finite and non-finite verbs in all Middle French prose texts

The non-finite verbs are constitutive of dependent clauses, and the independent infinitive clauses found in Old French (in (8a)) are not attested. The items by which the dependent infinitives are commanded furthermore relate to two types of environments. The first is speech verbs (10 in Morée - conseillie and conseillèrent 'advice', dist et deffendi 'said and forbade', donnés votre foi 'swear on your faith', jurèrent and jurement 'swear', promit and promirent 'promise', requeroit 'require', seremens 'oath' -, 2 out of 13 in Froissart - desfendi 'forbade' and s'escuse 'to excuse oneself', -, all 3 in Monstrelet - bailleraient seurté 'assured', délibérés 'decided', promis 'promised' -, all 3 in Artois - conclus 'concludes', conseille 'advise', fait serment 'swears' -, 1 out of 6 in de la Salle - promis -, 4 out of 16 in Cent Nouvelles excuser 'excuse', jurer 'swear', proposé et promis 'proposed and promised', promist 'promised', 1 dire 'say' in Commynes, and 1 out of 5 in Rabelais - promesse 'promise'.

(12) a. si fu conseillie de non mettre sa question en court (Monstrelet) he was indeed advised not to put in question to court

b. nuls povres bacelers de bonne volenté s'escuse de non querir les armes (Froissart)

some poor young man of good will excuses himself of not fetching the weapons

c. et avoit promis de luy non plus logier sur les pays duditduc de Bourgongne (Saintrée)

and he had promised not to stay in the said country of the duke of Burgundy 
d. et aussy pour tous dangiers vous conseille de non jamais porter la verge (Artois)

and also whatever the danger I advise you not to ever bear a stick

e. leur dist tout hault qu'il supplioit au roy non vouloir riens entreprendre sur le pays de Bretaigne (Commynes)

he told them out loud that he begged the king not to attempt anything on the country of Britanny

Containing a high proportion of speech-act verbs, these make explicit the speech-act dimension of the direct finite construction that as noted above can communicate denial, agreement, promises and so on. Irrealis contexts constitute the second major environment in which the infinitives are found: 10 in Morée (1 cessat 'stopped (doing something)', 1 destourber 'disturbed', 1 empeschie 'stopped (someone from doing something)', 1 furent en point de 'be on the verge of', 4 pour 'for', 2 tint de 'refrained from'), 11 out of 13 in Froissart (2 cesser 'stopped', delairoit 'to delay', deporte, deporté, deportee and deportoit 'removed', imagination et pourpos 'project and aim', respiter 'to grant respite', sauver 'saved', sousfers 'refrained'), 5 out of 6 in de la Salle (1 deffendu 'forbidden', 1 gardez 'be careful', 2 pour 'for', 1 question, although rhetorical), 8 out of 16 in Cent Nouvelles (1 affin de 'so that', 1 difficile 'difficult', 1 doute 'doubt', 1 espoir 'hope', 1 faisoient semblant 'pretended', 1 perdre espérance 'lose hope', 1 puisse 'could' and 1 correlative structure), 2 out of 3 in Commynes (erreurs 'mistakes', pour 'for') and 2 in Rabelais (contristait 'saddened', plaisir 'pleasure'). These contexts suggest a reanalysis of non modifying an infinitive verb as a negative polarity construction. The fact that negative polarity status is also generally assumed to characterise emerging post-verbal negatives suggests that such status is a property that can be attributed to marked negatives. Negative polarity status is analogous to the attested expletive uses (4 in Morée, 2 in Froissart, 2 in de la Salle, 2 in Cent Nouvelles), in that both are dependent upon a non-veridical environment.

(13) a. et lui dist privéement et deffendi de non passer R[obert ]. (Monstrelet) and he told him privately and forbid him to [not] pass Robert

b. mais li rois desfendi a non ardoir l'abeie pour tant que il i avoit esté logié (Froissart)

but the king forbade to [not] burn the abbey as long as they had been staying there

c. bien vous gardez de non oblier les tres glorieuses et pardurables richesses (Saintrée)

be very careful to [not] forget the very glorious and last wealth

d. $\quad$ Et pource qu'il avait douté de non pouvoir venir a la ville (Cent Nouvelles) And because he had doubted to [not] be able to come to town

Not contributing to the interpretation of the sequence following which the negative could be omitted salva veritate, these uses are exceptional in that they are assumed to characterise weak ne and are not expected with infinitives with which they are exceedingly rare in French at least from the Classical period (Larrivée 1994). Some occurrences in texts at the end of the period fall outside these two distributional contexts, with 4 in Cent Nouvelles and 3 in Rabelais. These two types of contexts do not impinge on the distribution of present participles that are mostly adjuncts.

The dependent status of non-finites should have a bearing on the pragmatic status of the construction, as explicit activation is stereotypically represented by an autonomous sentence denying an antecedent proposition, and lack of autonomy characterises non-finite verbs. This expectation is borne out by the data. Thus, finite 
contexts all associate to explicit activation, which applies only to a handful of infinitives, 1 in Morée, and 2 in Froissart, and not always in the immediately preceding environment as illustrated below (the relevant underlined sequences being the object of the translation):

Je le vous remonstre, car il est heure que vous le desfiés, se le desfiier le devés." Li dus de Braibant se vei pris en parole; et convenoit / que il respondesist, ne plus ne pooit requler ne faire nulle disimulation ; et si estoit li plus proçains que li rois d'Engleterre euist la. Et li fu avis trop grant blame li seroit de dire non. Si respondi et dist si hault que tout l'oirent: "Che que je me sui sousfers jusques a chi a non desfiier le roi de France, [...]. (Froissart)

It is time that you challenge him, if challenge him you must.

- What I have withstood so far is to not challenge the King of France

in which the question of whether the Duke of Brabant should challenge the King of France is raised before it is taken up by the Duke himself. None of the other infinitive uses and none of the present participles but one in Rabelais ("ceux qui ont femme soient comme non ayans femme" "those who have a wife should be as though they do not have a wife') are explicitly activated.

The loss of activated value with non-finites verbs and the increasing use of non with them is accompanied by a process of lexical diversification. Presumed to also characterise post-verbal negatives initially used with a limited set of predicates, the use of preverbal non with a larger set of lexically different verbs happens with non-activated nonfinite contexts: activated finite environments are found with the same limited number of verbs. Lexical diversification is demonstrated by dividing the number of lexically different verbs by the number of occurrences, which yield over six times more variety in nonfinite contexts as in finite ones: while nearly two infinitives our of three occurrences represent a different lemma, it takes ten occurrences of finite verbs before we get a different lemma. The number and identity of verbs is summarised in the table below:

\begin{tabular}{|c|c|c|}
\hline & Finite verb & Non-finite \\
\hline Chronique de Morée (1320-24) & pensent, place & $\begin{array}{l}2 \text { aler, deffaire, descendre, } 2 \\
\text { descovrir, donner, entrer, } 2 \\
\text { estre, faillir, faire, ferir, } \\
\text { guerroier, mettre, partir, } \\
\text { passer, } 2 \text { porter, rompre }\end{array}$ \\
\hline $\begin{array}{l}\text { Froissart: Chroniques (1369- } \\
\text { 1400) }\end{array}$ & 2 etre, 8 faire, 1 pouvoir & $\begin{array}{l}2 \text { aler, } 2 \text { ardoir }(+2 \text { etre } \\
\text { ars }(\mathrm{e})) \text {, cachier, desfiler, } 3 \\
\text { estre, querir, tenir }\end{array}$ \\
\hline $\begin{array}{l}\text { Les XV Joyes de Mariage } \\
\text { (around 1400) }\end{array}$ & 6 faire & \\
\hline $\begin{array}{l}\text { Enguerrand de Monstrelet : } \\
\text { Chronique (excerpts) (1441) }\end{array}$ & & Combatre, faire, logier \\
\hline $\begin{array}{l}\text { Le Roman du Comte d'Artois } \\
(1453-67)\end{array}$ & etre, 4 faire & avoir, porter, retourner \\
\hline $\begin{array}{l}\text { Antoine de la Sale: Jeban de } \\
\text { Saintrée (1456) }\end{array}$ & 5 faire, 3 avoir, 2 etre & $\begin{array}{l}\text { convoier, cuidant, mectre, } \\
\text { oblier, parler, porter, } \\
\text { sentant, troubler }\end{array}$ \\
\hline Les Cent Nouvelles Nouvelles & 11 avoir, 3 etre, 17 faire & comparoir, croire, entrer, \\
\hline
\end{tabular}




\begin{tabular}{|c|c|c|}
\hline$(1456-1467)$ & & $\begin{array}{l}\text { etre, } 2 \text { faire, fourbir, hanter, } \\
\text { jurer, paier, pervenir, } 2 \\
\text { pensant, povoir (venir), } \\
\text { querant, } 4 \text { recognoistre, } \\
\text { resister, } 4 \text { sachant, } \\
\text { trespasser, vouloir (marier) }\end{array}$ \\
\hline $\begin{array}{l}\text { Le Roman de Jehan de Paris } \\
\text { (1494) }\end{array}$ & 2 faire & \\
\hline $\begin{array}{ll}\text { Commynes: } & \text { Mémoires } \\
\text { (vers1490-1505) }\end{array}$ & meïst & advertir, avoir, vouloir \\
\hline $\begin{array}{l}\text { Rabelais: Le Tiers Livre } \\
\text { (1546) }\end{array}$ & etre, 2 faire & $\begin{array}{l}2 \text { ayant, consommer, dire, } \\
\text { doubtant, esconduire, } \\
\text { estant, entendent, laisser, } \\
\text { obstant, povant, povoir, } \\
\text { tenentes }\end{array}$ \\
\hline & $\begin{array}{llll}0.09 \quad(7 & \text { lemmas } \\
\text { occurrences) }\end{array}$ & $\begin{array}{l}0.60 \quad(52 \text { lemmas } / 86 \\
\text { occurrences) }\end{array}$ \\
\hline
\end{tabular}

Table 4. Lexical variety of the finite and non-finite verbs modified by non

These numbers provide empirical proof that a marked negative that loses its pragmatic specialisation extends to a large( $\mathrm{r}$ ) set of contexts.

One phenomenon where there is no clear evolution pattern is that of negative concord. Preverbal non has 2 uses with nul and 1 with plus in Morée, 1 with plus in Monstrelet, 1 with mulle in de la Salle, 1 with nuls in Froissart, 1 use with jamais in Artois, 1 with oncques, 2 with pas, 1 with point, 3 with jamais, 3 with plus in Cent Nouvelles, 1 with riens and 1 with plus in Commynes, 1 with aucuns and 1 with personne in Rabelais.

Significant changes occur in the use of preverbal non is Middle French. It extends increasingly to dependent environments beyond the root finite clauses where it is essentially found in Old French. Constructions other than the immediate direct reaction to the intervention of another speaker represent nearly half the occurrences with finite verbs. This extension to dependent contexts includes new non-finite environments that become the main context where preverbal non is found. This environment almost never associates to activation, which is typically found with a autonomous sequence that denies a previous intervention by another speaker. As activation is lost, a new role must be found to justify the use of preverbal non with infinitives; contextual dependency on a speech verb or on an irrealis context is emerging, without one of them succeeding in imposing itself. The loss of activation with non-finites is also correlated to an extension of the number of lexical verbs with which non is used. The failure to associate to one clear pragmatic function leads to the decline of non that cannot hope to become the default negative in the face of the well-established embracing negative ne ... pas.

The decline of non provides empirical grounding for the assumptions that a marked negative may be supported by a pragmatic function of activation. The loss of pragmatic function is signalled by an extension of the lexical variety and a reanalysis of contexts of use. The failure to acquire default status or a new marked function is the condition of the observed decline.

\section{Conclusions}

In Old French, preverbal negative non attaches to vicarious finite verbs be, bave, do to comment on an immediately preceding proposition, with an explicit pragmatic activated value that is associated with finite verbs. This function seems to lose ground as non extends to non-finite predicates in Middle French. As dependent events, infinitives do 
not have the foregrounded discourse status that would allow them to easily deny an antecedent proposition. This leads in the $17^{\text {th }}$ century to the loss of non that cannot gain default status against a well-established ne ... pas.

The detailed examination of the Middle French prose texts of the Base de francais médieval establishes the role of activation for the evolution of negatives. It evidences that explicit activation supports the marked negative used with finite verbs in a categorical way, and the one case of implicit activation is found in later Old French. This suggest that implicit activation is subsequent to explicit activation, and this supports the scenario that post-verbal negatives in Old French attested mainly in implicitly activated contexts may have been explicitly activated in an earlier unattested period. In other words, that post-verbal negatives cannot be diagnosed as explicitly activated in early French texts may not be a conclusive argument against the speculation that they once were: if we had only $16^{\text {th }}$ century texts, we would be incapable of (dis)proving that non was initially an activated marker. Activation is lost for the marked negative when it is used with nonfinite verbs in Middle French: in those contexts, it undergoes lexical diversification, and is found with six times the number of lexically different verbs than in finite contexts. This supports the speculation that post-verbal negatives had a distribution limited to a few verbs as polarity items before they evolved towards gaining default status. The loss of pragmatic justification for the non with non-finites leads to attempts at reanalysing the construction, but neither polarity contexts nor dependency to speech-act verbs succeeds in imposing itself. Again, this militates in favour of the received idea about the Jespersen cycle that polarity contexts bridged the change of status of what were to become postverbal negatives. Use in dependent contexts is a feature of the evolution of non with finite verbs, which come to be used increasingly in conjunct or embedded sequences rather than in root sequences reacting to the intervention of another speaker that dominate in Old French.

Hard empirical evidence is provided by this paper that marked negatives can be supported by a pragmatic value of activation, and that as this values is lost, the marker must be either adopted as default, reanalysed as having a different marked contribution or decline. The role of pragmatics for the evolution of grammar is therefore to prop up marked items that may change status in the relevant paradigm ${ }^{10}$. This concerns both emerging and declining marked items compared to the default expression of the category.

The research on which these conclusions are based raises a number of issues for future research. Relating to the history of negatives in French, the loss of non may be hastened by factors other than pragmatic. Syntactically, the loss of preverbal strong clitics (Goldbach 2008 and references therein) may have favoured ne over non, as it did se over soy for instance. The fact that the preverbal positive si 'indeed' was never to be found with infinitives (Richard Ingham, personal communication) may have had a role in the decline. Competition needs to be assessed with other activated markers, such as sentential nenny 'Not at all!' (2 nenil in La Vie de Saint Louis (1298-1309), 11 nennil in Froissart : Chroniques (entre 1369 et 1400), 4 nanil in Les XV Joyes de Mariage (vers 1400), 7 nanil in Le Roman du Comte d'Artois (1453-67), 1 nenil, 2 nennil in Antoine de la Sale : Jehan

\footnotetext{
${ }^{10}$ And I would concur with the reviewer's comments that " pragmatics can play other roles as well in the process of change, saliently that of triggering reanalyses of items and constructions ». It would seem that on the whole the change in pragmatic status and the possession of a pragmatic status seem to be two aspects of the same general phenomenon by which pragmatic values characterise some members of a grammatical paradigm to make evolution possible as these values change.
} 
de Saintrée (1456), 5 nenny in Le Roman de Jehan de Paris (1494)). Concerning the role of pragmatics in the evolution of grammatical paradigms, the dynamics of marked and default is often treated as an obvious factor (for instance Kawaguchi 2009, Waltereit 2009), but what the relations is between markers at critical moments of change needs to be better documented. Empirically grounded study of well-attested changes will no doubt provide a better understanding of the role of pragmatics for the evolution of grammatical paradigms.

\section{References}

Breitbarth, Anne, Haegeman, Liliane, 2010. Not continuity but change: stable stage II in Jespersen's yycle. MS, University of Cambridge and University of Ghent. 63 pages.

Buridant, Claude, 2000. Grammaire nouvelle de l'ancien français. Sedes, Paris.

Chen, Pi-Yin, 2010. La négation de l'infinitif en français classique. Étude de morpho-syntaxe variationnelle. PhD thesis, Université de Limoges.

Collas, John P. 1964. Problems of language and interpretation. Year Books of Edward II. Volume XXV. Selden Society, London.

Detges, Ulrich, Waltereit, Richard, 2002. Grammaticalization vs. reanalysis: a semanticpragmatic account of functional change in grammar. Zeitschrift für Sprachwissenschaft 21, 151-95.

Dryer, Matthew S., 1996. Focus, pragmatic Presupposition, and Activated Propositions. Journal of Pragmatics 26, 475-523.

Eckardt, Regine, 2006. From Step to Negation: The development of French complex negation. Meaning Change in Grammaticalization: An Enquiry Into Semantic Reanalysis. Chapter 5. Oxford University Press, Oxford.

García Bascuñana, Juan F., 1993. En torno a la formación y evolución de la negación compuesta en francés antiguo y medio. Anales de Filología Francesa 5, 49-64. Available at http://www.um.es/ojs/index.php/analesff/article/view/17081

Godard, Danielle, Marandin, Jean-Marie 2006. Reinforced negation: The Case of Italian. In: Müller, Stefan (Ed.), Proceedings of the HPSG06 conference. CSLI, Stanford, pp. 174-194.

Goldbach, Maria. 2008. Morphological developments affecting syntactic change. In: Detges, Ulrich, Waltereit, Richard (Eds), The Paradox of Grammatical Change: Perspectives from Romance. Benjamins, Amsterdam, pp. 85-106.

Guiraud, Pierre, 1964. L'opposition virtuel / actuel : remarques sur l'adverbe de négation. In: Aucassin et Nicolette. Mélanges offerts à M. Delbouille. Tome 1. Duculot, Paris et Gembloux, pp. 295-306.

Himmelmann, Nikolaus, 2004. Lexicalization and grammaticalization: opposite or orthogonal? In: Bisang, B., Himmelmann, N., Wiemer, B. (Eds.), What Makes Grammaticalization: A look from its fringes and components. Mouton de Gruyter, Berlin and New York, pp. 21-42.

Hirschbühler, Paul, Labelle, Marie, 1997. La syntaxe de position dans les infinitivales négatives en moyen français. In: Combettes, Bernard, Monsonégo, Simone (Eds), Le moyen français. Philologie et linguistique; approches du texte et du discours. Actes du VIIIe Colloque international sur le moyen-français. Didier Érudition, Paris, pp. 483-506.

Hoeksema, Jack, 2009. Jespersen Recycled. In: Gelderen, Elly van (Ed.), Cyclical Change. Benjamins, Amsterdam, 15-34.

Hopper, Paul J. and Elizabeth C. Traugott, 2003. Grammaticalization. Cambridge University Press, Cambridge. 
Ingham, Richard, 2009. The discourse particle si in later Anglo-Norman dialogic texts. Paper read at the International Conference Meaning and Interaction, April 23-25 2008, University of the West of England.

Jespersen, Otto, 1917. Negation in English and other languages. A. F. Høst, Copenhagen.

Kawaguchi, Yuji, 2009. Particules négatives du français : ne, pas, point, mie. Un aperçu historique. In: Martineau, France (Ed.), Le français d'un continent à l'autre. Mélanges offerts à Yves Charles Morin. Presses de l'Université Laval, Québec, pp. 193-210.

Kiparsky, Paul, Condoravdi, Cleo, 2006. Tracking Jespersen's Cycle. In: Janse, Mark, Joseph, Brian D., Ralli, Angela (Eds), Proceedings of the 2nd International Conference of Modern Greek Dialects and Linguistic Theory. University of Patras, Patras, pp. 172-197. Available at http://www.stanford.edu/ kiparsky/

Larrivée, Pierre, 2010. The Pragmatic motifs of the Jespersen Cycle: Default, Activation, and the History of Negation in French. Lingua 120,9, 2240-2258.

Larrivée, Pierre, 2009. Positive Polarity Items, Negation, Activated Propositions. MS, Aston University. 22 pages.

Larrivée, Pierre. 1994. Commentaires explétifs à propos d'un certain emploi de ne. Linguisticae investigationes 18 (1), 175-186

Martin, Robert, 1972. La négation de virtualité en moyen-français. Romania 93, $20-49$.

Mellet, Sylvie. 1992. L'aternance ne / non en latin classique. L'Information grammaticale 55, 28-32.

Moignet, Gérard, 1965. L'opposition non - ne en ancien français. Travaux de linguistique et de littérature 3 (1), 46-66.

Mosegaard Hansen, Maj-Britt, Visconti, Jacqueline, 2007. On the diachrony of reinforced negation in French and Italian. In: Rossari, Corinne, Ricci, Claudia, Spiridon, Adriana (Eds), Grammaticalization and Pragmatics: Facts, approaches, theoretical issues. Emerald, Bingley, pp. 137-171.

Opperman, Evelyne, 2003. Les emplois des infinitifs jussifs et prohibitifs. Thélème special issue, 161-170.

Orlandini, Anna, 2001. Négation et argumentation en latin. Peeters, Louvain.

Reid, T. B. W., 1939. Non, nen and ne with finite verbs in French. In: Studies in French Language and Mediaeval Literature: Presented to Professor Mildred K. Pope by pupils, colleagues and friends. Manchester University Press, Manchester, 305-313.

Schøsler, Lene, 2008. Manuscrits du Charroi de Nimes. Paper read at the seminar of Cycles of Grammaticalization, August 2 2008, Aston University. Hand-out, University of Copenhagen, 8 pages. Available at http://www1.aston.ac.uk/EasySiteWeb/GatewayLink.aspx?alId=15323

Schwenter, Scott A., 2006. Fine-tuning Jespersen's cycle. In: Birner, Betty J., Ward, Gregory (Eds), Drawing the boundaries of meaning. Neo-Gricean studies in honour of Laurence R. Horn. Benjamins, Amsterdam and Philadelphia, pp. 327-344.

Schwenter, Scott A., 2005. The Pragmatics of negation in Brazilian Portuguese. Lingua $115,1427-1456$.

Taylor, Robert, 1976. Les préfixes de négation non et nient en ancien français. Actes du 13e Congrès international de linguistique et de philologie romanes. Klincksieck, Paris, pp. 647-658.

Traugott, Elisabeth C. 2008. All that he endeavoured to prove was: On the emergence of grammatical constructions in dialogal and dialogic contexts. In: Kempson, Ruth, Cooper, Robin (Eds), Language in flux: Variation, Change and Evolution. Kings College publication, London, 143-177.

van Hoecke, Willy, 2006. Le développement de l'adverbe non comme marque de la négation partielle en français. In: Bel, Catherine, Braet, Herman, Dumont, Pascale and 
Willaert, Frank (Eds), Mélanges de langue et de littérature médiévales offerts Herman Braet. Peeters, Louvain, pp. 797-812.

Vanbrabant, Anita, 1994. L'évolution du système de la négation en français. Une étude empirique fondée sur les traductions du 'De Inventione ' de Cicéron par Jean d'Antioche (1282) et Henri Bornecque (1932). MA Thesis, Université de Louvain.

Vance, Barbara, 1997. Syntactic change in medieval French. Kluwer, Dordrecht.

Visconti, Jacqueline, 2009. From "textual" to "interpersonal": On the diachrony of the Italian particle mica. Journal of Pragmatics 41 (5), 937-950.

Waltereit, Richard, 2009. On the decline of the stressed reflexive in the history of French. Paper read at the International Conference Meaning and Interaction, April 23-25 2008, University of the West of England. 